\title{
Settlement Dynamics and Site Hierarchies in Western Sicily from the Fourth to Seventh Centuries AD: Interpretative Challenges in the Contessa Entellina Survey
}

\author{
Antonino Facella \\ Soprintendenza per i Beni Archeologici della Calabria, Italy \\ Scuola Normale Superiore di Pisa, Italy \\ email: antonino.facella@sns.it
}

\begin{abstract}
The Contessa Entellina survey is an intensive and systematic archaeological survey carried out in western Sicily, on an area extending over $136.4 \mathrm{~km}^{2}$, out of which more than $114 \mathrm{~km}^{2}$ were physically covered. The observation of settlement trends from the fourth to seventh centuries shows, on first glance, a noticeable drop in the number of sites from the third to fourth centuries, a new rise in the fifth century and a dramatic fall around the end of the century, followed by a period of stability or slow decrease throughout the sixth and seventh centuries. A more detailed analysis reveals, on the other hand, a much higher density of fifth century diagnostic artefacts (per site and per settled hectare), when compared with the previous and the two following centuries. The fifth century is therefore much more "visible" on the ground, and this may have contributed to the higher identification of fifth century sites.

The massive presence of fifth century artefacts may not be exclusively due to a population increase: economic and socio-cultural factors most likely also came into play, distorting the resulting settlement picture. More precisely, a possible higher tendency towards a grain monoculture may have caused a massive import of African foodstuffs (attested by amphorae) between the late fourth and the middle fifth century, and peculiar dietary customs could explain the all-pervading diffusion of African Red Slip Ware cups belonging to the form Hayes 80-81. Similarly, if we take into consideration also less diagnostic artefacts such as roof tiles, we find that the fall in the number of sites
\end{abstract}

between the end of the fifth and the sixth-seventh centuries may have been less drastic than it appears, and that it was followed by attempts to work out new settlement strategies, showing a fairly good resilience.

Keywords: Settlement Trends, Late Antiquity, Sicily, Archaeological Survey, Rural Population

The Contessa Entellina survey (fig. 1) was a systematic intensive archaeological survey in the territory of the modern municipality of Contessa Entellina (province of Palermo) in western Sicily, carried out from 1998 to 2004 by the Laboratorio di Scienze dell'Antichità of the Scuola Normale di Pisa (for preliminary information and contributions on specific topics, see the references mentioned in Facella et al, 2014: 529, note 1). The surveyed area was $136.4 \mathrm{~km}^{2}$, out of which more than 114 $\mathrm{km}^{2}$ were physically covered lon methodology, see Facella, in press a). A total of 282 sites, and more than 150 off-site finds (that we were able to delimit and map, thanks to the absence of a real "background noise" carpet) have been identified. It is my responsibility to study settlement dynamics in Late Antiquity, precisely from the fourth to the seventh century AD. At least 74 archaeological sites and numerous off-site finds (around 40) can be dated within this period; full publication of the results is forthcoming (Facella, in press b).

In this paper, I will focus on some interpretative aspects that to me seem essential for the reconstruction of late antique settlement trends 


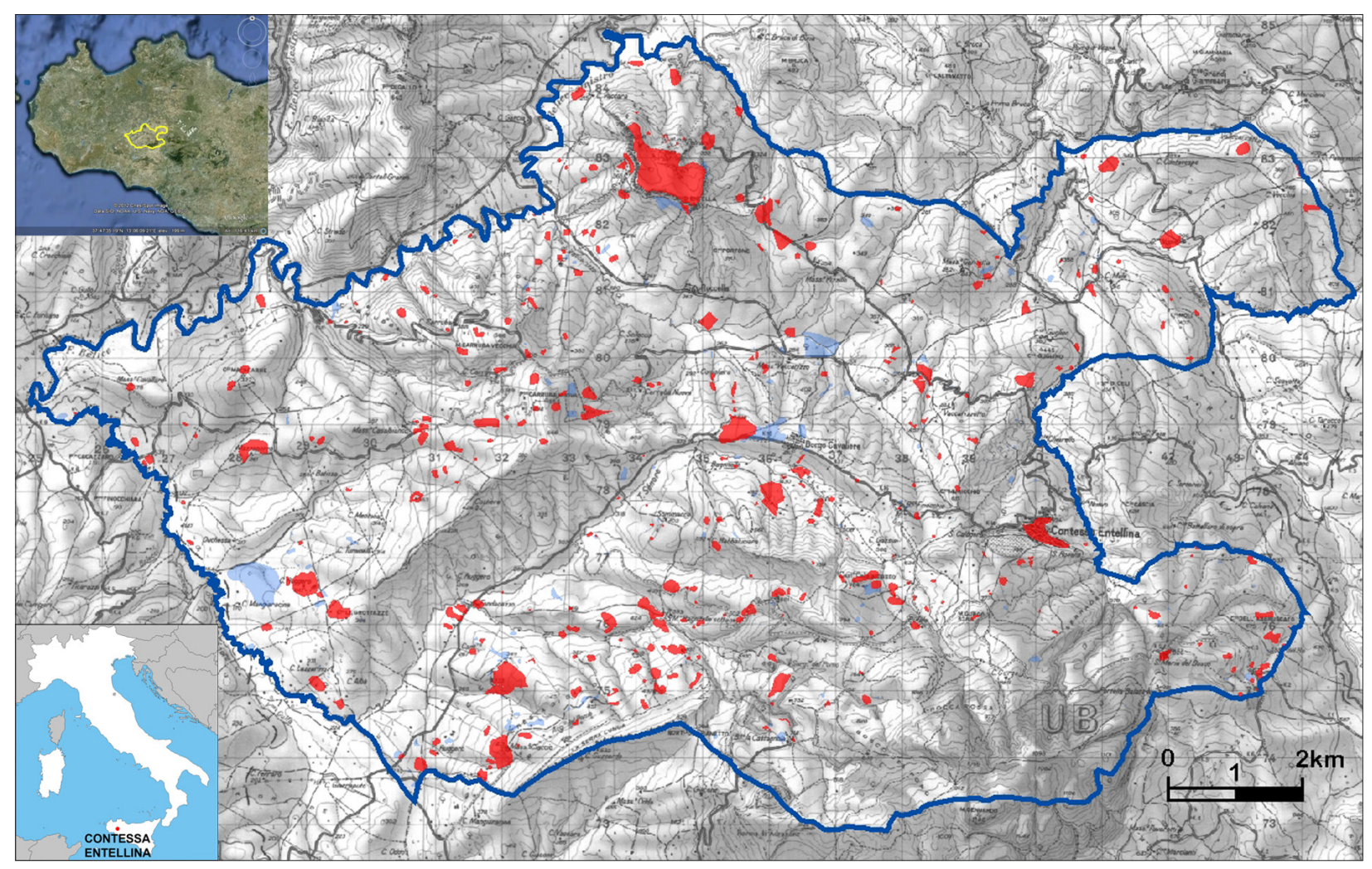

Fig. 1. Contessa Entellina survey: sites (red) and off-site finds (pale blue).

in the investigated area. Our success in extracting sensible meanings and applying models depends not only on the reliability of the data under analysis, always subject to improvement and refinement to the best, but also on our ability to filter them through a correct scheme of interpretation. I would like to start from what is usually a conclusive point: a brief description of settlement trends from the fourth to the seventh century AD, based on a crude analysis of "raw" data.

In the investigated area we can identify a remarkable stability in site location and settlement patterns between the Early - Middle Imperial Age and the fourth century and beyond: many sites that are active in the first and second centuries $A D$ are still alive in the fourth century, even if from the third century we notice, in some of them, important typological changes, for example Early Imperial villas that spread and become veritable villages (Vaggioli, in press). Between the third and fourth centuries the level of continuity in site location is significantly high, but a dramatic drop in the number of sites, from 70 certain sites (plus eight probable) to 35 (plus eleven probable), seems at first sight to be detectable.

In the fifth century we instead notice an apparent new and considerable rise in the number of settlements: we count 56 certain sites, plus two probable (figs. 2-3). Settlement in the investigated area seems therefore to become more all-pervading. A remarkable increase in the extent of settled areas is also detectable (fig. 3 ).

Almost all sites that are active in the fourth century, on the other hand, seem to continue their life in the following century. Settlement continuity between the fourth and the fifth centuries therefore seems unquestionable and the site-replacement rate is very low, conforming to the trend detected in the first three centuries AD. In the fourth-fifth centuries we can ascertain the existence of a complex hierarchical settlement pattern, given the contemporary presence of estate-centres provided with luxury residential sectors (villas), villages (vici), a possible "agro-town" (the 


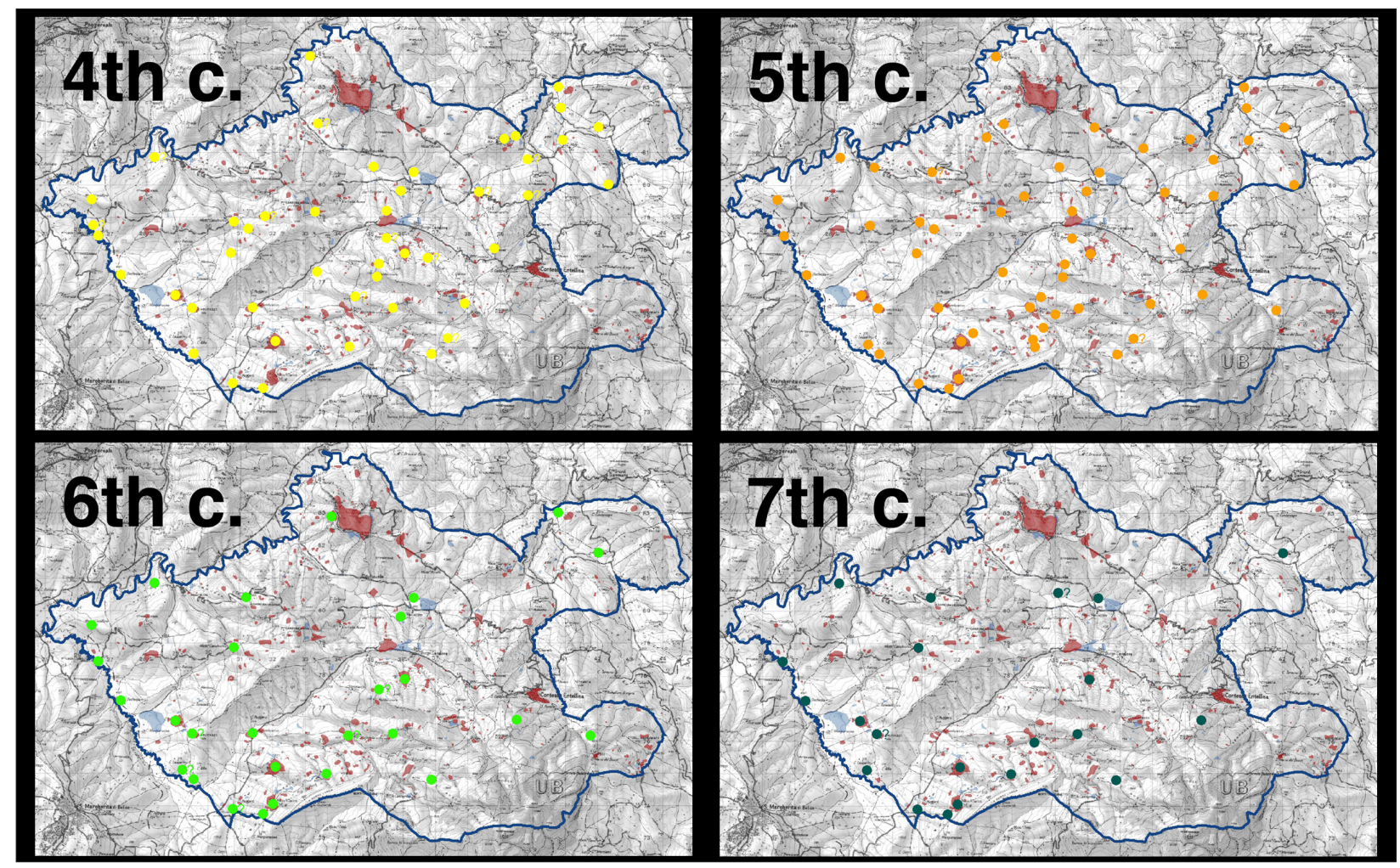

Fig. 2. Contessa Entellina survey: fourth, fifth, sixth and seventh century sites.

settlement of Miccina, over 17 ha wide; on "agrotowns", see Wilson, 1990: 232-33), and large-, medium- and small-sized isolated farms.

At the end of the fifth century, a dramatic fall seems to occur in the number of rural settlements, as well as in the extent of settled areas (figs. 2-3): for the sixth century we count only 23 sites (plus five probable); this fall is even more marked in the central and eastern portion of the investigated area, and can be interpreted as the result of systemic transformations in the land set-up, followed by a phase of new stability in settlement patterns, lasting probably - as we will see - up to the late eighth century. Between the sixth and seventh century, we notice a strength in the number of sites and in the extension of settled areas (figs. 2-3), and the persistence of a remarkable settlement continuity: almost all seventh century sites (nineteen, plus two probable) had been already active in the former century, and most of

them are long-lived settlements that had arisen in the Early Imperial, Late Republican, Hellenistic, or even Archaic/Classical Age.

Sixth-seventh century sites appear to be well distributed in the territory: inter-distances between them are around 2-3 km, with very few exceptions. Settlement organisation seems to still be rather hierarchical and complex. We can identify:

1) very large-sized sites (more than 4 ha), that can no doubt be interpreted as villages, usually quite far from each other;

2) large-sized sites loften, Imperial Age villas that continued in or returned to a settled state in the sixth-seventh centuries, although the nature of settlement seems now not very clear, and the material evidence is usually much more scanty compared with the two former centuries); and

3) medium- and small-sized sites (less then $1 \mathrm{ha}$ ), even if considerably less in number compared with the fifth century.

Among the factors that permitted some sites to survive the strong selection of the late fifth century and continue into the sixth-seventh 


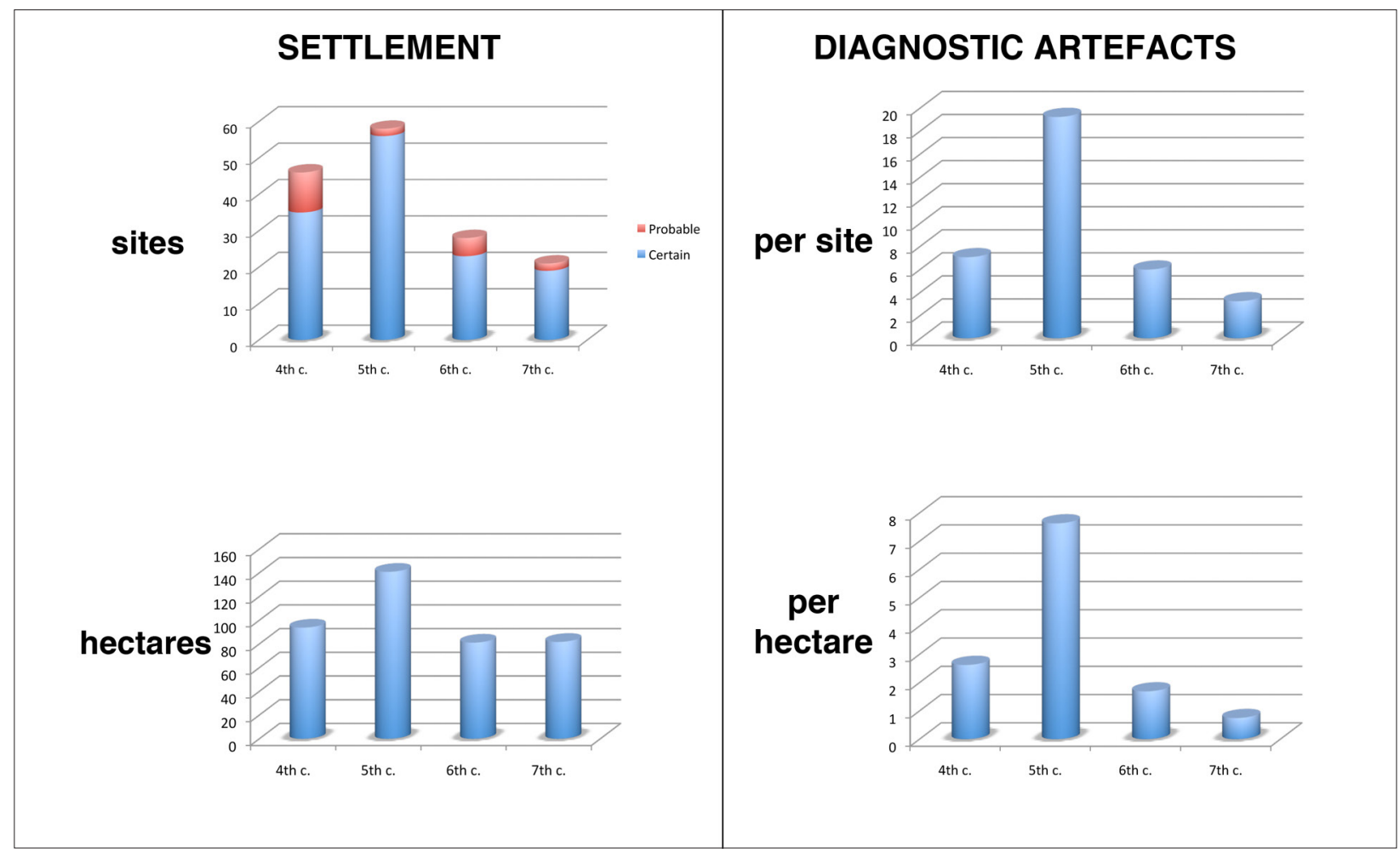

Fig. 3. Contessa Entellina survey: sites and extent of settled areas (left); average of diagnostic artefacts per site and per hectare (right).

centuries, we must consider proximity to major roads, and above all, size: a feature that seems to remain important over time. The few sixth century sites that do not reach the seventh century are all small to medium-sized sites, and all large sixth century villages remain settled in the following century, although in a more rarefied way. The only significant variation in settlement patterns between sixth and seventh centuries is precisely a further reduction in the number of small sites.

In general, late-antique settlement dynamics in the investigated area reveal a twofold tendency, both to the development of nucleated settlement and to the rarefaction of medium- and small-sized sites, the second being a possible evidence of progressive concentration of land property. Both are long-lasting trends, detectable from the Early Imperial Age onwards, and find close comparisons with other areas of Sicily (development of villag- es: Alfano \& Sacco, 2014: 34; Bergemann, 2011 : 92-97; Cambi, 2005: 629-30; Di Stefano, 1997: 459; Fentress, Kennet \& Valenti, 1986: 85; Johns, 1992: 414; Maurici et al, 2014: 23; Molinari \& Neri, 2004: 122; Molinari, 2014: 336; Vaccaro, 2013: 281; Wilson, 1990: 223-36; decrease of small sites and concentration of landholdings: Belvedere, 2002: 394; Bernardini et al, 2000: 116-22; Cacciaguerra, 2011: 293-95; Cambi, 2005: 630-34; Molinari \& Neri, 2004: 115; Wilson, 1990: 234). This is, in short, the general picture emerging from a first analysis. In order to check whether this provides a reliable or distorted picture, the data that led to this first interpretation have been analysed to greater depth.

Let us start from the first striking phenomenon: is the fall in the number of fourth century sites, compared to the third and fifth centuries, really as marked as it seems? And do the fluctuations in the extent of settled areas point to population variation? If we look carefully, out of the fourteen sites that seem to arise ex-novo in the fifth century, a solid nine reveal to have been certainly settled in the second-third centuries AD. Can we be absolutely certain that, at least for these sites, 


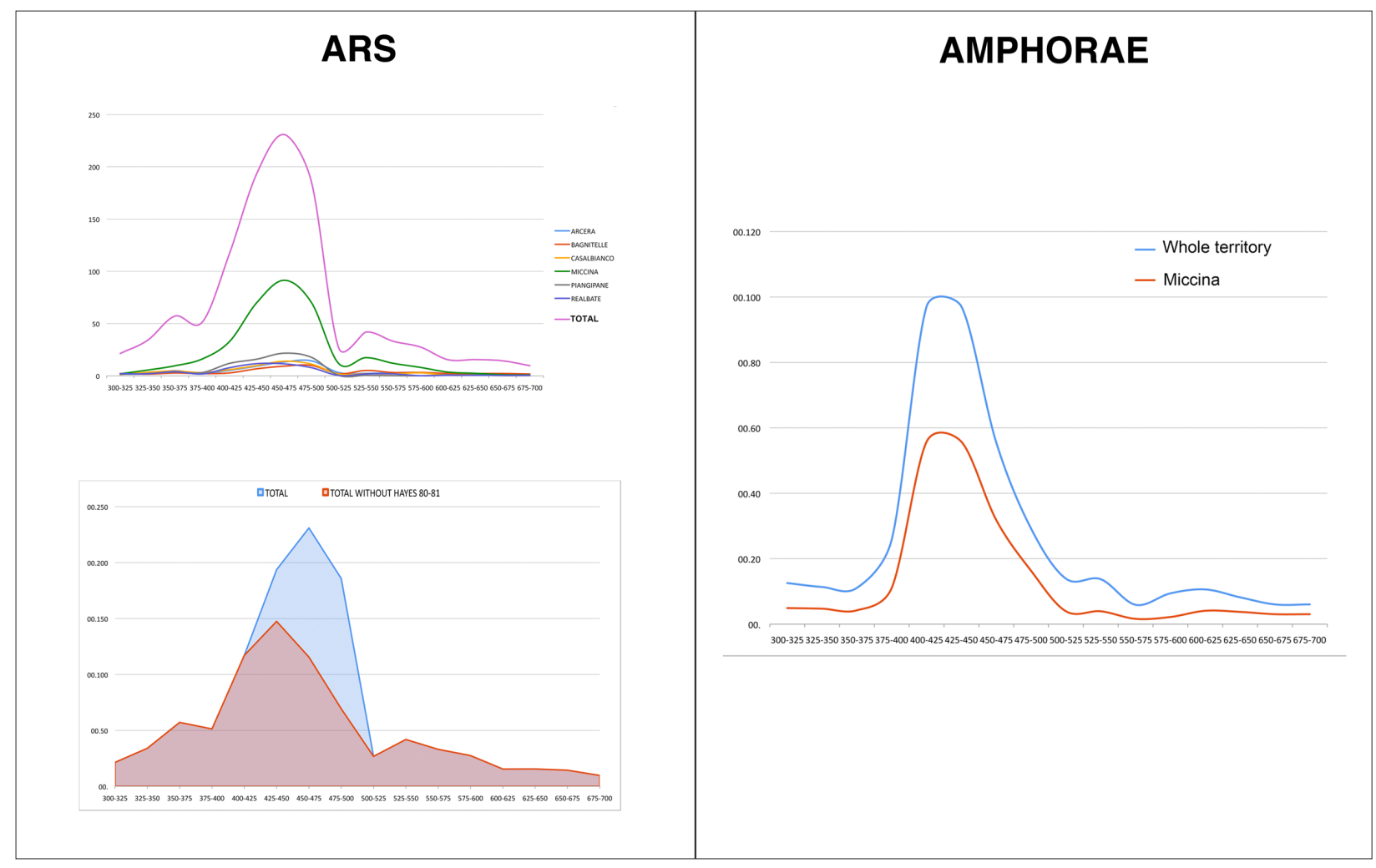

Fig. 4. Contessa Entellina survey: ARS ware (left) and amphorae (right) from fourth to seventh centuries AD. The chronology of each specimen has been equally divided into quinquennia, then grouped in 25 years periods.

the gap in fourth century evidence is due to a lack of settlement and not more simply to a lower density - in surface assemblages - of artefacts that can be dated to the fourth century? Such rarity, if confirmed, could indeed make a fourth century phase less easy to identify.

I accordingly made a chart that shows the average of diagnostic artefacts (mainly, but not only, fine wares and amphorae) per site in each of the four centuries (considering only the sites that are certainly alive in that centuryl, and another chart with the average of diagnostic artefacts per settled hectare (fig. 3, right). Interestingly, the two charts are very similar, and this appears to be a sign of reliability of the results. As one can see, the difference between fourth and fifth centuries is remarkable, as well as between fifth and sixth-seventh centuries. The diagnostic artefacts that can be ascribed to fifth century are much more numerous than those of the former and the two following centuries, and the increase in the number of finds is clearly greater than the increase in the extent of settled areas from fourth to fifth century. The fourth century seems therefore to be undoubtedly less "visible" than the fifth.

Hence, out of the fourteen "new" fifth century sites only the five sites that were not knowingly settled in the second-third centuries can be confidently considered to describe "genuinely" new settlements lalthough most of these were actually simply resettled, after a gap of several centuries). Three out of five are very close to other contemporary settlements, to which they could be linked as a sort of satellite, and only two (that can be interpreted as medium-size farms) arise in an isolated position.

The higher density of fifth century diagnostic artefacts in the area of Contessa Entellina does not seem to be a completely isolated phenomenon in Sicily: it has been observed, for example, at Sofiana, in the central part of the island IVaccaro, 
2013: 284-86), and probably (since most of fifth century diagnostic ceramics are imports from Africal in some western coastal sites as well, like Carabollace and Verdura, as noted by M. Bonifay on the basis of the assemblages of African pottery (Malfitana \& Bonifay, in press).

But, how can we explain it? Should we think of a higher population density per hectare lthat is: more people) in the fifth century, compared to the fourth? Or a higher power to acquire certain goods by the rural population (that is: the same number of people, yet wealthier)? Or of different cultural practices (that is: the same number of people now using more artefacts)? Or, better, of a combination of demographic, socio-economic and cultural factors?

It is not easy to answer such questions. Besides, a more in-depth analysis shows that the fifth century peak in the Contessa Entellina survey is actually the result of the combined massive presence of two different artefact classes: Imainlyl amphorae for the first half of the century, and (mainly) African Red Slip Ware (ARS) for the period ranging approximately from 440 to 500 .

If we look at a chart which shows the trend of amphorae finds in the four centuries under examination (fig. 4, right), both in the most important site (Miccina, a veritable Late Antique "agro-town", as stated abovel and in the whole Contessa Entellina survey (including Miccina), we see that the increase in the number of finds is much greater than the increase in the extent of settled areas from fourth to fifth century, and the highest peak falls in the first half of the fifth century.

The fifth century amphorae found in the survey are, for the largest part, imports from Africa: besides salsamenta, they also transported wine and - probably to a lesser extent - olive oil: foodstuffs that the land in the Contessa Entellina district was undoubtedly capable of producing in abundance. It is possible, therefore, that their very high number indicates for our area in the fifth century a stronger tendency towards a grain monoculture, addressed to exportation (to Rome and Suburbium, above all), with a local production of olive oil and wine insufficient to entirely meet the population demand Isimilar considerations on other districts of central and western Sicily in Cambi, 2005: 632-33; Filippi, 2003: 502; Lentini, 2010: 211-12; Molinari, 2002: 334; Rizzo et al, 2014: 218; on Italy in general, Vera, 1997: 54-55). On the other hand, it shows a market opened up to imported products, and a strong level of integration in an interregional exchange network.

Such a tendency towards a wheat monoculture appears to predate the Vandal conquest of Africa (439, capture of Carthage) and the final interruption of the annona from North Africa (455) that gave Sicily an essential role as a grain supplier in the annona system. Rather, it could be linked to the great development of grain production in the island after the diversion of the Egyptian canon frumentarius to the new metropolis of Constantinople (332), with much of Sicilian surplus probably finding an outlet in the free market (Vera, 1997; 2005: 28-30; 2010; Wilson, 1990: 189).

A second chart (fig. 4, top left) shows the chronological distribution of ARS from the fourth to seventh centuries in the six major sites of the Contessa Entellina survey leach one providing from circa 60 to circa 360 records) compared to the total finds from the whole survey. I took only rims into consideration (so as not to overestimate the forms that are detectable also from decorated body-sherds and bottoms), for a total of about 1100 records.

If we compare the "total" line with the number of sites per century, we clearly see the higher density of diagnostic artefacts in the fifth century, with a peak in the third quarter of the century. We also note that there are no significant differences in the behaviour of each one of the six major sites, but - as well as for the amphorae - the higher the total number of artefacts, the greater the number of fifth century artefacts we find.

The picture of ARS between the fourth and the seventh centuries, on the other hand, does not appear to fully match that of the few Sicilian survey contexts so far analysed in detail, which show a peak in the second half of the fourth to the beginning of the fifth century (Fentress et al, 2004: 154; see also Bonacasa Carra \& Vitale, 1997: 385 , 


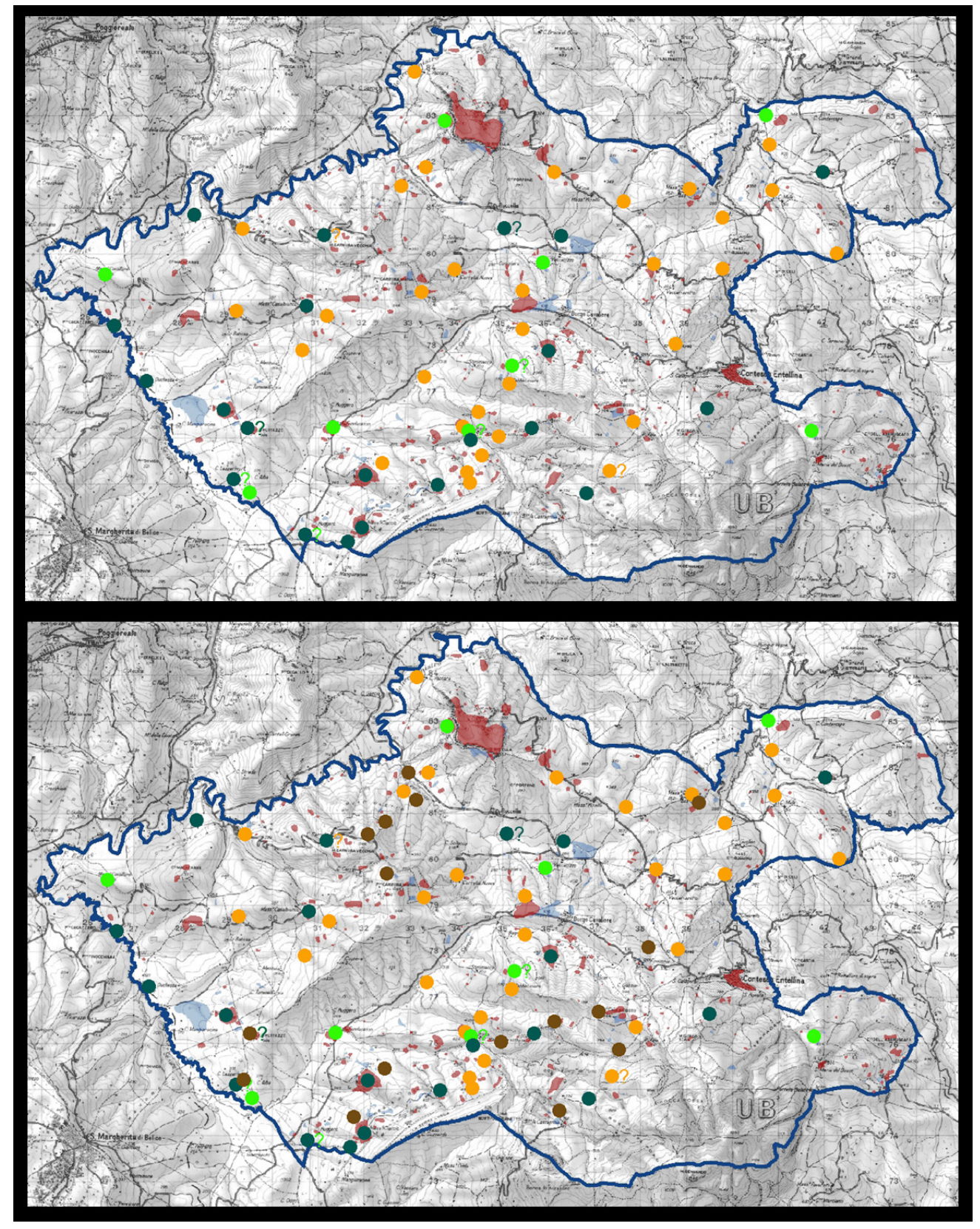

Fig. 5. Contessa Entellina survey: sites not surviving beyond the late fifth century (orange), sites not surviving beyond the sixth century (light green), seventh century sites (dark green), sites attested only by combed tiles (brown, bottom).

411) or in the first half of the fifth century lat Sofiana: Vaccaro, 2013: 290-94), and can find possible comparisons with just some sites of central-western Sicily, such as Verdura and Carabollace Isee above). Again, do we have to explain the ARS picture in mid and late fifth century as the result of a higher population density per hectare, or did other factors, economic and cultural, come into play?

An aspect that could point to differences in material culture is that of the cup Hayes 80-81. This form is extremely widespread in mid-late fifth century assemblages from the investigated area (in particular, the type Hayes 81A: over 250 records out of 360): even excluding body sherds (where Hayes 81A are over-represented), Hayes 80-81 
represent over $42 \%$ out of the total amount of fifth century ARS D from the investigated area (Facella et al, 2014: 532 fig. 6). In this case as well, the massive presence of the Hayes 81A does not seem peculiar to our territory: it has been reported also at Agrigento and its hinterland (Bonifay in Malfitana \& Bonifay, in press; Castellana \& McConnell, 1990: 34), in the Platani river valley (Rizzo, 2004 : passim) and at Monte Pellegrino, near Palermo (Di Stefano, Garofano \& Gandolfo, 1997: 13). However, for Sicily as a whole this form does not appear to be particularly common (Bonacasa, Carra \& Vitale, 1997: 411, 441). The shape of this cup, fairly deep and measuring some $15-20 \mathrm{~cm}$ in diameter, points clearly towards the individual consumption of liquids or semi-liquid food, for instance soup or porridge. Such a dietary custom would require, for each household, a larger pottery set, provided with individual cups, when compared to the habit of meals consisting only of food served on one large communal plate.

Thus, if we remake the chart of "total" ARS, this time not counting Hayes 80-81 (fig. 4, bottom (eft), we observe that the density of fifth century ARS decreases noticeably, though remaining higher than the density in the other three centuries, and the ARS trend from fourth to seventh centuries is now closer to the trend of the number and extent of sites.

It seems therefore that specific economic processes and peculiar aspects of material culture related to the most diagnostic artefact classes, that is ARS and amphorae, may have provoked a greater visibility of fifth century sites, contributing to an "inflated" difference between their number and that of identified fourth, sixth and seventh century sites.

Another issue that deserves a closer examination is the seeming fall in the number of sites from fifth to sixth-seventh centuries. As for North Africa, C. Wickham has warned us on the fall in the number of identified sixth-seventh centuries settlements, which is usually interpreted as depopulation and land abandonment, but may rather be linked to a decreasing presence of fine ware: 'I would argue that most of the changes in these field surveys have to do with ARS availability [...] rather than with settlement'. As a matter of fact, where it has been possible (as at Douggal to establish firm chronologies even for coarse ware, sixth-seventh century sites have multiplied (Wickham, 2005: 723-24; similar considerations on Italy: Bintliff, 2012: 70). This could be valid for Sicily too, where many surveys seem to reveal a remarkable fall in settlements' number from the fourth-fifth to sixth-seventh centuries (Bernardini et al, 2000: 116-22; Bonacini, 2007: 90, 94; Burgio, 2002: 15859, 164; 2008: 256-57; Cacciaguerra, 2009: 299; 2011: 293-95; 2014: 380-81; Cambi, 2005: 633; Fentress, Kennet \& Valenti, 1986: 81; Filippi, 2002: 377-79; Giordano, 1997: 347; Giordano \& Valentino, 2004: 18; Maurici, 2005: 213, 217, 255; Molinari, 2002: 325-28; Molinari \& Neri 2004: 115; Rizzo, 2004: 148; 2005: 642; 2010: 285-86; Rizzo, Danile \& Zambito, 2014: 352; Rotolo \& Martín Civantos: 2012, 414; Vaccaro, 2013: 281), and where, in sixth-seventh centuries, diagnostic artefacts do indeed represent a small percentage of the total amount of ceramic finds le.g., at Segesta: Facella, 2013: 294-95; Facella, Capelli \& Piazza, 2013: $50-$ 51; Facella, Minniti \& Capelli, 2014).

In the Contessa Entellina survey, the study of sixth-seventh century cooking ware and coarse ware, most of which were locally produced, is still in progress, and we are not yet able to create a reliable chronologic grid. Diagnostic sherds are still, for the most part, fine wares, lamps and amphorae.

Nevertheless, we can take advantage of another "index fossil": combed roof tiles. In Sicily, tiles decorated with combed lines appear in the last quarter of the fifth century, and remain in use at least until the end of the seventh century (Arcifa, 2010a: 108-11; 2010b: 28-29; Rotolo \& Martín Civantos, 2012, 414; Wilson, 1979, 23; 1999: 538). Of course, non-combed tiles can still be found in sixth century contexts, due to the practice of reiterated reutilisation (after the collapse of a roof) of tiles that remained in good condition. Similarly, we can find combed tiles even in eighth century contexts, when new roof tiles, with vacuolated fabric, begin to appear (first, both combed and vacuolated, then, only vacuolated: Alfano, 2014: 251; Alfano 
\& Sacco, 2014: 9; Cacciaguerra, Facella \& Zambito, 2015: 208-09 with further bibliography; Rizzo, 2001: 250-51; 2004: 147). We can thus assume that if we find combed non-vacuolated tiles, then there is a very high probability that they refer to a sixth-seventh century settlement. For this reason, I tried to identify sites with no sixth-seventh century diagnostic sherds, but that did produce combed tiles. Unfortunately, in the Contessa Entellina survey, roof tiles have only been sampled. For this reason, I have only taken into consideration sites that produced at least two samples of combed tiles or more, assuming that multiple sampling implies a significant presence on the ground.

In this way, we are able to identify at least sixteen sites attested only by combed tiles. Adding these to the sixth-seventh century sites identified by diagnostic sherds, which number 30 , we reach a total of 46 sixth-seventh century sites, only ten less than the fifth century certainly-active sites and only sixteen less than fourth and fifth century sites combined. Interestingly, as you can see from the comparison of these two images (fig. 5), sixth-seventh century sites attested only by combed tiles (fig. 5 bottom, in brown) do not correspond simply to sites already settled in the fifth century, nor are they located close by: hence they can neither be considered mere continuators nor substitutes of fifth century sites. Moreover, they are all, apparently, small-size settlements, located in fairly secluded areas and showing no hierarchical relations between each other.

Undoubtedly, the massive abandonment in the late fifth century of at least 25 sites, often following a several centuries-old existence, is indicative of a strong discontinuity, and probably of a systemic collapse. Sites attested only by combed tiles seem to show an attempt, after the crisis, to "colonise" new areas, previously unsettled, at least in a couple of sectors (NNW and SSE) of the investigated area. For the first time since the Augustan Age we notice a new approach to the territory, and some lalthough limited) innovations in settlement strategies, while, to date, the emergence of new settlement patterns was detectable only for the late eighth-early ninth centuries (as we will see below).
To sum up, bias correction and closer analysis of available data have allowed us to soften some features that would have been depicted in a more dramatic way by superficial investigation and to reconstruct a more complex trend.

The increase in the number of sites from fourth to fifth century is probably overestimated since the presence of fifth century artefacts appears to be inflated by economic and cultural aspects. The phenomenon of the appearance of new sites in the fifth century could be downsized, and speculations on a possible population increase, or on "prosperity", should be softened. The hypothetical fifth century population increase, if ever there was one, may have been so dramatic and the few new sites could instead testify to simply a tendency to also settle "marginal" areas and more intensive land exploitation.

The systemic change that took place around the end of the fifth century brought about not just a decrease in number of sites, but also new answers and new settlement strategies. We can infer, in the sixth and seventh centuries, when the villa system does not seem to exist anymore, a still complex, hierarchical and rather all-pervading rural settlement system, with contemporary presence of villages of various size and structure, possible estate-centres, small- and medium-size isolated farmsteads, and maybe also scattered buildings with uncertain functions. Such a diversified settlement pattern is also symptomatic of economic complexity, and that a good level of integration remained in an exchange network on a Mediterranean scale. A fairly good resilience and ability to react to shocks, carrying out new strategies of land exploitation, is also noticeable - as shown by the first attempt to break from the centuries-old "Roman" settlement system - and partly disproves an apparent picture of full settlement continuity and conservativeness.

On the other hand, starting from the late eighth-early ninth centuries, we notice clear elements of rupture. A new settlement framework begins to appear: most of the seventh century sites now disappear and new small (or very small) sites arise, away from watercourses and main 
roads and in higher (but not hill-top) locations, apparently unstructured and similar to each other (Corretti, Facella \& Mangiaracina, 2014: 343-45; Corretti, Michelini \& Vaggioli, 2010: 170-73). This is not an isolated phenomenon, and can be detected in other areas of western and central Sicily ICacciaguerra, Facella \& Zambito, 2015: 203-04, with further bibliography; Rizzo, 2004: 152; 2010: 286; Rizzo, Danile \& Zambito, 2014: 352; Molinari, 2002: $334 ; 2014: 336)$. It is fascinating to think of these new sites as a result of relaxation of the double grip of taxation and latifundium, with the elites labove all local aristocracies, but the forfeiture of the Church properties in Sicily and Calabria to the patriarchate of Constantinople, in the thirties or - more probably: Prigent, 2004 - forties of the eighth century, also comes to mind) no longer able to exercise control over the peasant population, and consequent spread of small properties and the "colonisation" of "marginal" areas (Belvedere, 2004: 6-8; Belvedere, Burgio \& Cucco, 2014: 37172; Molinari, 2002: 334).

\section{References}

Alfano A, 2014: L'insediamento medievale nella valle dello Jato e del Belice destro: i primi risultati dalle ricognizioni di superficie, in Musco A \& Parrino G (ed.), Santi, santuari, pellegrinaggi. Atti del seminario internazionale di studio (San Giuseppe Jato-San Cipirello, 31 agosto - 4 settembre 2011): 237-68. Officina di Studi Medievali, Palermo.

Alfano A \& V Sacco 2014: Tra alto e basso medioevo. Ceramiche, merci e scambi nelle valli dello Jato e del Belice Destro dalle ricognizioni nel territorio (Palermo), in FOLD\&R Italy 309, www.fastionline.org/ docs/FOLDER-it-2014-309.pdf

Arcifa L, 2010a: Indicatori archeologici per l'alto Medioevo nella Sicilia orientale, in Pensabene P (ed.), Piazza Armerina. Villa del Casale e la Sicilia tra tardoantico e medioevo: 105-28. L'Erma di Bretschneider, Rome. Arcifa L, 2010b: Nuove ipotesi a partire dalla rilettura dei dati archeologici: la Sicilia orientale, in Nef A \& Prigent V (ed.), La Sicile de Byzance à l'Islam: 15-49. De Boccard, Paris.
Belvedere 0, 2002: L'evoluzione storica del territorio imerese dalla fondazione della colonia al periodo tardo-antico, in Belvedere O, Bertini A, Boschian G, Burgio A, Contino A, Cucco RM \& Lauro D (ed.), Himera 3.2 Prospezione archeologica nel territorio: 377-97. L'Erma di Bretschneider, Rome.

Belvedere 0, 2004: Dal medioevo alla tarda antichità: gli esiti di una ricerca, in Rizzo MS (ed.), L'insediamento medievale nella valle del Platani: 1-10. L'Erma di Bretschneider, Rome.

Belvedere 0, A Burgio \& RM Cucco 2014: Evidenze altomedievali nelle valli dei fiumi Torto e Imera settentrionale, in Nef A \& Ardizzone F (ed.), Les dynamiques de l'islamisation en Méditerranée centrale et en Sicile: nouvelles propositions et découvertes récentes: 365-72. École française de Rome, Rome/ Edipuglia, Bari.

Bergemann J, 2011: Il Gela-survey: 3000 anni di insediamenti e storia nella Sicilia centromeridionale, Sicilia Antiqua, 8, 63-100.

Bernardini S, F Cambi, A Molinari \& I Neri 2000: Il territorio di Segesta fra l'età arcaica e il Medioevo. Nuovi dati dalla carta archeologica di Calatafimi, in Terze Giornate Internazionali di Studi sull'Area Elima. Atti del Convegno (Gibellina-Erice-Contessa Entellina, 23-26 ottobre 1997): 91-133. Scuola Normale Superiore di Pisa/Comune di Gibellina, Pisa-Gibellina.

Bintliff J, 2012: The paradoxes of Late Antiquity: a thermodynamic solution, Antiquité Tardive, 20, 69-73.

Bonacasa Carra RM \& E Vitale 1997: Ceramiche di produzione locale e ceramiche d'importazione nella Sicilia tardoantica, Kokalos, 43-44, 377-452.

Bonacini E, 2007: Il territorio calatino nella Sicilia imperiale e tardoromana, Archaeopress, Oxford.

Burgio A, 2002: Resuttano: IGM 260 III SO (Forma Italiae 42), Leo S. Olschki, Florence.

Burgio A, 2008: Il paesaggio agrario nella Sicilia ellenistico-romana. Alesa e il suo territorio, L’Erma di Bretschneider, Rome.

Cacciaguerra G, 2009: Dinamiche insediative in Sicilia tra $V$ e X secolo: tre contesti a confronto nell'area megarese, in Volpe G \& Favia P (ed.), V Congresso nazionale di Archeologia Medievale (Foggia-Manfredonia, 30 settembre - 3 ottobre 2009): 296-301. All'Insegna del Giglio, Florence.

Cacciaguerra G, 2011: Il territorio di Priolo Gargallo tra 
l'età romana e medievale: considerazioni conclusive, in Malfitana D \& Cacciaguerra G (ed.), Priolo romana, tardo romana e medievale: 285-305. IBAM CNR, Catania.

Cacciaguerra G, 2014: L'area megarese tra il IX e l'XI secolo: un paesaggio in transizione, in Nef $A$ \& Ardizzone F (ed.), Les dynamiques de l'islamisation en Méditerranée centrale et en Sicile: nouvelles propositions et découvertes récentes: 379-87. École française de Rome, Rome/Edipuglia, Bari.

Cacciaguerra G, A Facella \& L Zambito 2015: Continuity and Discontinuity in Seventh-Century Sicily: Rural Settlement and Economy, in Gnasso A, Intagliata EE, MacMaster TJ, Morris BN (ed.), The Long Seventh Century: Continuity and Discontinuity in an Age of Transition: 199-233. Peter Lang, Bern.

Cambi F, 2005: Segesta. I villaggi di età imperiale, in Volpe G \& Turchiano M (ed.), Paesaggi e insediamenti rurali in Italia meridionale fra Tardoantico e Altomedioevo. Atti del Primo Seminario sul Tardoantico e l'Altomedioevo in Italia meridionale (Foggia, 12-14 febbraio 2004): 623-40. Edipuglia, Bari.

Castellana G \& BE McConnell 1990: A Rural Settlement of Imperial and Byzantine Date in Contrada Saraceno near Agrigento, Sicily, American Journal of Archaeology, 94(1), 25-44.

Corretti A, C Michelini \& MA Vaggioli 2010: Frammenti di Medioevo siciliano: Entella e il suo territorio dall'alto Medioevo a Federico II, in Pensabene P (ed.), Piazza Armerina. Villa del Casale e la Sicilia tra tardoantico e medioevo: 147-96. L’Erma di Bretschneider, Rome.

Corretti A, A Facella \& CF Mangiaracina 2014, Contessa Entellina (PA). Forme di insediamento tra tarda antichità e età islamica, in Nef A \& Ardizzone F (ed.), Les dynamiques de l'islamisation en Méditerranée centrale et en Sicile: nouvelles propositions et découvertes récentes: 341-49. École française de Rome, Rome/Edipuglia, Bari.

Di Stefano CA, 1997: Testimonianze archeologiche della tarda età romana nella provincia di Palermo, Kokalos, 43-44, 453-62.

Di Stefano CA, I Garofano \& L Gandolfo 1997: Ricerche archeologiche sul Monte Pellegrino (Palermo), in Greco C, Spatafora F \& Vassallo S (ed.), Archeologia e territorio: 3-24. Palumbo, Palermo.

Facella A, 2013: Nuove acquisizioni su Segesta tardoan- tica, Annali della Scuola Normale Superiore di Pisa, 5(5/1), 285-315 \& 448-51.

Facella A (in press a): La metodologia d'indagine, in Entella II. Carta archeologica del Comune di Contessa Entellina, Edizioni della Normale, Pisa.

Facella A (in press b): La tarda antichità, in Entella II. Carta archeologica del Comune di Contessa Entellina, Edizioni della Normale, Pisa.

Facella A, C Capelli \& M Piazza 2013: L'approvvigionamento ceramico a Segesta nel VI-VII sec. d.C.: il contributo delle analisi archeometriche, Annali della Scuola Normale Superiore di Pisa, 5(5/2), 49-63.

Facella A, A Maccari, M Perna, P Puppo, MA Vaggioli \& D Zirone 2014: Artefacts assemblages and settlers' identity: case-studies from the Contessa Entellina survey (Augustean period - seventh century A.D.), Rei Cretariae Romanae Fautorum Acta, 43, 529-38.

Facella A, B Minniti \& C Capelli 2014: Ceramiche da un contesto tardoantico presso l'agorà di Segesta (TP), Rei Cretariae Romanae Fautorum Acta, 43, 539-46.

Fentress E, D Kennet \& I Valenti 1986: A Sicilian Villa and its Landscape (Contrada Mirabile, Mazara del Vallo, 1988), Opus, 5, 75-90.

Fentress E, S Fontana, RB Hitchner \& Ph Perkins 2004: Accounting for ARS: fineware and sites in Sicily and Africa, in Alcock SE \& Cherry JF (ed.), Side-by-side Survey. Comparative Regional Studies in the Mediterranean World: 147-62. Oxbow Books, Oxford.

Filippi A, 2002: Da Alcamo a Trapani. L'abitato rurale fra l'età imperiale e l'alto medioevo, in Bonacasa Carra RM (ed.), Byzantino-Sicula IV. Atti del I Congresso Internazionale di Archeologia della Sicilia bizantina (Corleone, 28 luglio - 2 agosto 1998): 375-83. Istituto Siciliano di Studi Bizantini e Neoellenici, Palermo.

Filippi A, 2003: Indagini topografiche nel territorio di Erice e Trapani, in Quarte Giornate Internazionali di Studi sull'Area Elima. Atti: 497-506. Scuola Normale Superiore, Pisa.

Giordano P, 1997: Ricerche a Montagna dei Cavalli. Ricognizioni nel territorio, in Greco C, Spatafora F \& Vassallo S (ed.), Archeologia e territorio: 337-48. Palumbo, Palermo.

Giordano P \& M Valentino 2004: Carta archeologica del territorio comunale di Lercara Friddi, ISPE Archimede, Palermo.

Johns J, 1992: Monreale Survey. L'insediamento umano 
nell'alto Belice dall'età paleolitica al 1250 d.C., in Giornate Internazionali di Studi sull'Area Elima (Gibellina, 19-22 settembre 1991). Atti, vol. 1: 40720. Scuola Normale Superiore di Pisa - Comune di Gibellina, Pisa-Gibellina.

Lentini F, 2010: Il territorio di Selinunte in età imperiale, in Tusa S (ed.), Selinunte: 205-18. L’Erma di Bretschneider, Rome.

Malfitana D \& M Bonifay (in press): La ceramica africana nella Sicilia romana, Lecce.

Maurici F, 2005: La Sicilia occidentale dalla tarda antichità alla conquista islamica. Una storia del territorio ca. 300-827 d.C., Regione Siciliana, Palermo.

Maurici F, A Alfano, S Muratore, F Salamone \& A Scuderi 2014: Il "Castellazzo" di Monte lato in Sicilia occidentale (prov. di Palermo). Terza e quarta campagna di scavo. Ricognizioni nel territorio, FOLD\&R Italy 317, www.fastionline.org/docs/FOLDER-it-2014-317. pdf

Molinari A, 2002: Insediamento rurale e fortificazioni nella Sicilia occidentale in età bizantina. Vecchi e nuovi dati su Segesta e Selinunte, in Bonacasa Carra RM (ed.), Byzantino-Sicula IV. Atti del I Congresso Internazionale di Archeologia della Sicilia bizantina (Corleone, 28 luglio - 2 agosto 1998): 323-53. Istituto Siciliano di Studi Bizantini e Neoellenici, Palermo.

Molinari A, 2014: Le ricerche nel territorio di Segesta-Calathamet-Calatafimi: ripensando ad un ventennio di ricerche nella Sicilia occidentale, in Nef A \& Ardizzone F (ed.), Les dynamiques de l'islamisation en Méditerranée centrale et en Sicile: nouvelles propositions et découvertes récentes: 327-39. École française de Rome, Rome/Edipuglia, Bari.

Molinari A \& I Neri 2004: Dall'età tardo-imperiale al XIII secolo. I risultati delle ricognizioni di superficie nel territorio di Calatafimi/Segesta (1995-1999), Mélanges de l'Ecole française de Rome. Moyen Âge, 116, 109-27.

Prigent V, 2004: Les empereurs isauriens et la confiscation des patrimoines pontificaux d'Italie du sud, Mélanges de l'Ecole française de Rome. Moyen Âge, 116, 557-94.

Rizzo MS, 2000: Le dinamiche del popolamento rurale di età tardoantica e medievale nella Sicilia centromeridionale, in Brogiolo GP (ed.), II congresso nazionale di archeologia medievale (Brescia, 28 settembre - 1 ottobre 2000): 249-53. All'Insegna del Giglio, Florence.

Rizzo MS, 2004: L'insediamento medievale nella valle del Platani, L'Erma di Bretschneider, Rome.

Rizzo MS, 2005: L'insediamento rurale nella Valle del Platani tra Tardoantico e Altomedioevo, in Volpe G \& Turchiano M (ed.), Paesaggi e insediamenti rurali in Italia meridionale fra Tardoantico e Altomedioevo. Atti del Primo Seminario sul Tardoantico e l'Altomedioevo in Italia meridionale (Foggia, 12-14 febbraio 2004): 641-47. Edipuglia, Bari.

Rizzo MS, 2010: L'abitato rurale nell'agrigentino nella prima età bizantina (VI-VII secolo), in Congiu M, Modeo S \& Arnone M (ed.), La Sicilia bizantina: storia, città e territorio. Atti del VI Convegno di Studi (Caltanissetta, 9-10 maggio 2009): 277-95. Sciascia, Caltanissetta/Rome.

Rizzo MS, L Danile \& L Zambito 2014: L'insediamento rurale nel territorio di Agrigento: nuovi dati da prospezioni e scavi, in Nef A \& Ardizzone F (ed.), Les dynamiques de l'islamisation en Méditerranée centrale et en Sicile: nouvelles propositions et découvertes récentes: 351-63. École française de Rome, Rome/ Edipuglia, Bari.

Rizzo MS, L Zambito, F Giannici, R Giarrusso \& A Mulone 2014: Anfore di tipo siciliano dal territorio di Agrigento, in Poulou-Papadimitriou N, Nodarou E \& Kilikoglou V (ed.), LRCW4. Late Roman Coarse Wares, Cooking Wares and Amphorae in the Mediterranean. Archaeology and Archaeometry. The Mediterranean: a market without frontiers: 213-23. Archaeopress, Oxford.

Rotolo A \& JM Martín Civantos 2012: Il territorio dei monti di Trapani in epoca islamica. Primi risultati dall'“Idrisi Project”-ARPATRA, in Redi F \& Forgione A (ed.), VI Congresso Nazionale di Archeologia Medievale (L'Aquila, 12-15 settembre 2012): 413-18. All'Insegna del Giglio, Florence.

Vaccaro E, 2013: Patterning the Late Antique economies of inland Sicily in a Mediterranean context, in Lavan $L$ (ed.), Local economies? Production and Exchange of Inland Regions in Late Antiquity: 259-313. Brill, Leiden.

Vaggioli MA, (in press): La prima e la media età imperiale: da Augusto alla riforma di Diocleziano 130 a.C. - 293 d.C.J, in Entella II. Carta archeologica del 
Comune di Contessa Entellina, Edizioni della Norma-

le, Pisa.

Vera D, 1997: Fra Egitto ed Africa, fra Roma e Costantinopoli, fra annona e commercio: la Sicilia nel Mediterraneo tardoantico, Kokalos, 43-44, 33-73.

Vera D, 2005: I paesaggi rurali del Meridione tardoantico: bilancio consuntivo e preventivo, in Volpe $G$ \& Turchiano M (ed.), Paesaggi e insediamenti rurali in Italia meridionale fra Tardoantico e Altomedioevo. Atti del Primo Seminario sul Tardoantico e l'Altomedioevo in Italia meridionale (Foggia, 12-14 febbraio 2004): 23-38. Edipuglia, Bari.

Vera D, 2010: Fisco, annona e commercio nel Mediterraneo tardoantico: destini incrociati o vite parallele?, in Menchelli S, Santoro S, Pasquinucci M \& Guiducci G (ed.), LRCW3. Late Roman Coarse Wares, Cooking Wares and Amphorae in the Mediterranean. Archaeology and Archaeometry. Comparison between western end eastern Mediterranean: 1-18. Archaeopress, Oxford.

Wickham C, 2005: Framing the Early Middle Ages. Europe and the Mediterranean, 400-800, Oxford University Press, Oxford.

Wilson RJA, 1979: Brick and tiles in Roman Sicily, in McWhirr A (ed.), Roman Brick and Tile: studies in manufacture, distribution and use in the Western Empire: 11-43. British Archaeological Reports, Oxford.

Wilson RJA, 1990: Sicily under the Roman Empire. The Archaeology of a Roman Province (36 BC - AD 535), Aris and Phillips, Warminster.

Wilson RJA, 1999: Iscrizioni su manufatti siciliani in età ellenistico-romana, in Gulletta MI (ed.), Sicilia Epigraphica. Atti del Convegno Internazionale (Erice, 15-18 ottobre 1998), Annali della Scuola Normale Superiore di Pisa, Quaderni, 8, 531-55. 
